\title{
Alternative Intake Station in Saguling Reservoir for The Needs of Raw Water in Bandung Metropolitan Area
}

\author{
Mariana Marselina ${ }^{1, *}$, Arwin Sabar ${ }^{1}$, Indah R S Salami ${ }^{1}$ and Dyah Marganingrum ${ }^{2}$ \\ ${ }^{1}$ Faculty of Civil and Environmental Engineering, Institut Teknologi Bandung, Indonesia \\ ${ }^{2}$ Indonesian Institute of Science, Indonesia
}

\begin{abstract}
Bandung Metropolitan Area (BMA) region is the upper watershed of Citarum with an area of \pm $2338 \mathrm{~km}^{2}$. The status carried by BMA as a National Strategic Area from the perspective of economic encourage the increasing migration flows to BMA. These circumstances lead to an imbalance between supply and demand, in which on the one hand, demand for clean water is increasing. The potency of Saguling Reservoir as an alternative of raw water of BMA region in terms of quantity in this research was determined based on the determination of mainstay discharge. In this study, the intake site selection 11 monitoring posts will be carried out by reviewing the concentration of all parameters in Government Regulation No. 82 Year 2001 on any division of discharge grade using 5-grade Makov Discrete method (very dry, dry, normal, wet and very wet). In addition, the calculation of the value of Water Quality Index (WQI) was done at each monitoring station for each division of discharge grade that has been done. The series of data flow and concentration parameters used in this study start from the year 1999 to 2014. The allocation of raw water discharge calculation for Saguling Reservoir in order to fulfill the needs of raw water in Bandung Metropolitan Area is 46,92 $\mathrm{m}^{3} / \mathrm{second}$ (R5 dry for irrigation raw water supply and 29,53 $92 \mathrm{~m}^{3} / \mathrm{second}$ (R10 dry for drinking water supply). Based on the assessment of the concentration of measured parameters and determination of Water Quality Index, it can be found that around Muara Ciminyak location is the most qualified location to be used as drinking raw water intake for Bandung Metropolitan Area. Based on this study, it also notes that the determination of the concentration of pollutant parameters needs to be done on the each division of discharge grade occurred.
\end{abstract}

\section{Introduction}

Bandung Metropolitan Area (BMA) is an upstream of Citarum watershed with an area of $2338 \mathrm{~km}^{2}$ [6]. The status held by the BMA as a National Strategic Area with the point of economic interest plus various function carried out by Bandung City as the core of the region, turned out to be investors attraction to make investments that encourage the increasing migration flow. The increasing population and economic development and production activities in this region led to successive land conversion and the increasing water demand. This condition triggers an imbalance between supply and demand, were on one hand the demand for clean water increases and on the other hand the water source has suffered from quantity and quality degradation.

The utilization of the potency of Saguling Reservoir as raw water source has an impact on the changing of reservoir operating management from single function reservoir to multi-sector reservoir. Of course this condition needs careful target and preparation. Indepth calculation of Saguling Reservoir capability in terms of quantity and quality as raw water alternatives should be performed. Based on research from Hart et al (2007), Saguling was classifed as a eutropic reservoir.

The potency of Saguling Reservoir as raw water alternative in BMA region in terms of quantity in this research was determined based on the determination of mainstay discharge. Mainstay discharge is the discharge available in a watershed at a certain time which its existence is located to be able to meet the rate of water demand. The amount of this mainstay discharge can be determined by the ranking method (statistic historic) or rational.

The analysis of reservoir water quality was conducted by Water Quality Index method. The analysis of water quality status in this research was conducted by comparing the observation results with the standard values [19], [11], [18]. Evaluation of water quality can be conducted with spatial and temporal approach [1-5], [12], [20], [21]. Therefore, the availability of periodic and regular (time series) data monitoring is the success key in performing the water quality evaluation [14-17], [8], [9]. In addition to historical data series, the selection of appropriate water quality parameters is also a very important variable in evaluating the quality of water source [18], [20].

\footnotetext{
*Corresponding author: mariana.marselina@yahoo.com
} 
WQI shows the relative contamination levels allowed in water quality parameters or water quality parameter standards. Water quality parameter standards used in this WQI analysis refer to Government Regulation No. 82 of 2001 on the designation of water class. Saguling is categorized as class I because it is used for drinking water in downstream cascade Citarum.

Based on this research, it was understood that the mainstay discharge of drinking water of Saguling Reservoir by using the R10 concept as dry (the discharge value is less in one time within 10 years period). Based on the Water Quality Index research conducted, the monitoring location which become the best alternative as region or location of raw water intake can be found.

\section{Methodology}

\subsection{Mainstay Dicharge of Saguling Reservoir}

The reservoir discharge analysis is often associated with the reliability level of water availability in meeting the needs and is often referred to as mainstay discharge. For example, the activities that require the reliability of water availability is the provision of raw water and hydropower [13]. Mainstay discharge is determined by a certain minimum quantity that has a certain probability in meeting the needs, for example, for the needs of drinking raw water usually set as $90 \%$ or $95 \%$, while for irrigation is set as $80 \%$. The return period equation for probability is defined as $\operatorname{Tr}=(1 / \mathrm{P})$ in which $\operatorname{Tr}$ is the return period and $\mathrm{P}$ is the expected probability. The design criteria of domestic raw water and irrigation can be seen in Table 1 .

Table 1. Design Criteria of Domestic Raw Water and Irrigation

\begin{tabular}{|c|c|c|c|c|}
\hline $\begin{array}{c}\text { Reservoir Water } \\
\text { Source }\end{array}$ & \multicolumn{3}{|c|}{ Raw Water Planning Design Criteria } \\
\hline \multirow{2}{*}{$\begin{array}{c}\text { Successive Dry } \\
\text { Water Discharge }\end{array}$} & \multicolumn{2}{|c|}{ Domestic } & \multicolumn{2}{|c|}{ Irrigation } \\
\cline { 2 - 5 } & $\begin{array}{c}30 \\
\text { days }\end{array}$ & $\begin{array}{c}\mathrm{T}_{\mathrm{R}}=10-20 \\
\text { Years }\end{array}$ & $\begin{array}{c}30 \\
\text { days }\end{array}$ & $\begin{array}{c}\mathrm{T}_{\mathrm{R}}=5 \\
\text { Years }\end{array}$ \\
\hline
\end{tabular}

Source: Modified by Sabar (2009)

Observation of minimum discharge value and maximum discharge value is expected to provide an explanation for the water potential tendency in Saguling Reservoir. Discharge observation has been done in research by Marganingrum (2013) and Rhamdani (2009) in Saguling Reservoir in two periods, namely 1950-1985 (period of development and management planning of Saguling Reservoir) and 1986-2008 (period after the construction of Saguling Reservoir). An observation was also conducted on the minimum discharge trends from year to year as to provide an explanation on the potential base flow of watershed, while observation on the maximum discharge trends from year to year can provide explanation on floods or runoffs due to land-use changes. Furthermore, the observation of dischager in the research of Citarum Cascade Reservoir was conducted within the observation span of 1986-2013.

\subsection{Determinantion of Wet, Norma, and Dry Years with Markov Model}

Markov model has a formula as follows (Descombes dan Berthod, 2006):

where:

$$
\mathrm{q}_{\mathrm{i}}=\mathrm{d}_{\mathrm{i}}+\mathrm{e}_{\mathrm{i}}
$$

$\mathrm{di}=$ deterministic component

ei $=$ random component

Otoregresip deterministic component has a linear formula as follows:

$$
\mathrm{d}_{\mathrm{i}}=\beta_{0}+\beta_{1} \mathrm{q}_{\mathrm{t}-1}+\beta_{2} \mathrm{q}_{\mathrm{t}-2}+\ldots \ldots \ldots+\beta_{\mathrm{m}} \mathrm{q}_{\mathrm{t}-\mathrm{m}}
$$

where $\mathrm{d}_{\mathrm{i}}$ is a linear combination of $\mathrm{m}$ previous flow, for a limited $\mathrm{m}$. The simplest model has the following formula:

$$
d_{i}=\beta 0+\beta_{1} q_{t-1}+e_{1}
$$

The above model assumes that all previous influence to the flow is now reflected in the value of the previous flow. Furthermore, in lag model, the amount of $\beta_{0}$ dan $\beta_{1}$ constants are specified with the exact form of $e_{i}$. In the first place, it is considered that the flow follows the normal distribution.

If $\mu$ is the middle-value flow, $\rho$ is the correlation of coefficient serial lag and $\sigma$ is flow diversity, the following equation is established:

$$
\mathrm{q}_{1}=\mu+\rho\left(\mathrm{q}_{\mathrm{i}-1}-\mu\right)+\mathrm{e}_{\mathrm{i}}
$$

Here, it is assumed that the flow of qi is the sum of the median, some of the differences in previous flow $\mathrm{q}_{\mathrm{i}-1}$ with the mean and random components $e_{i}$. If $q_{i}$ has a normal distribution, then $e_{i}$ should also have a normal distribution as well. The flow of $\mathrm{q}_{i}$ has median $\mu$, so the suggested form will give the desired middle value. The flow $\mathrm{q}_{\mathrm{i}}$ has diversity as follows:

$$
\mathrm{E}\left[\mu+\left(\mathrm{q}_{\mathrm{i}-1-}-\mu\right)+\mathrm{e}_{\mathrm{i}}\right]^{2}-\mu^{2}=\sigma^{2} \rho^{2}+\sigma_{\mathrm{e}}^{2}
$$

where $\sigma_{\mathrm{e}}^{2}$ is a diversity of the random components ei. The diversity $\mathrm{q}_{\mathrm{i}}$ is related with $\sigma_{\mathrm{e}}{ }^{2}$ which expressed in the following formula:

$$
\mathrm{S}_{\mathrm{e}}^{2}=\sigma^{2}\left(1-\rho^{2}\right)
$$

If $t_{i}$ is a random variable that has a normal distribution, but does not serially rely on 0 median and has 1 value of standard deviation, then:

$$
\text { ti } \sigma((1-\rho 2))^{0,5}
$$

also, a normally distributed variable does not depend serially, on median 0 and variance $\sigma 2(1-\rho 2)$. Thus the model is as follows:

$$
\mathrm{q}_{\mathrm{i}}=\mu+\rho\left(\mathrm{q}_{\mathrm{i}-1-\mu)}+\mathrm{t}_{\mathrm{i}} \sigma\left(\left(1-\rho^{2}\right)\right)^{0,5}\right.
$$

Simplification of water discharge that entered the reservoir in Markov model was conducted by dividing them into three classes. Based on the water division, 
matrix stochastic can be created each month that divides the historical data into three classes. The stages of Markov model processing in dividing discharge category are as follows:

\section{a. Frequency distribution analysis}

An analysis of the frequency distributions of water discharge per month in the period 1999-2013 was conducted. Then the frequency distribution of historical data was matched with the two frequency distribution models: Normal and LogNormal. Each month, the most suitable distribution of the two alternative types was chosen

\section{b. Class division}

The second phase after the selection of frequency distribution was the distribution of water discharge class. The process investigated in this study was the first order for three classes. Therefore, the amount of discharge was divided into three classes as follows:

1) Dry discharge (represented by 0 )

2) Normal discharge (represented by 1 )

3) Wet discharge (represented by 2)

Class intervals for each class divisions was obtained by dividing the probability curve of the distribution of the selected population into 3 equal parts, namely 0.333 , 0.667 , and 1 as shown in Figure 1. Range value of each class was the middle value of each class which is in probability curve $0333,0.667$, and 1 . The probability determination of each data was conducted by using Weibull method as follows:

$$
\mathrm{P}(\mathrm{Xm})=\frac{\mathrm{m}}{\mathrm{N}+1}
$$

\section{with:}

$$
\begin{array}{ll}
\mathrm{P}(\mathrm{Xm}) \quad & \text { probability of a set of values that are } \\
& \text { expected during the observation period } \\
\mathrm{N} & =\text { number of observation of } \mathrm{X} \text { variate } \\
\mathrm{m} & =\text { serial number of events or rate of events }
\end{array}
$$

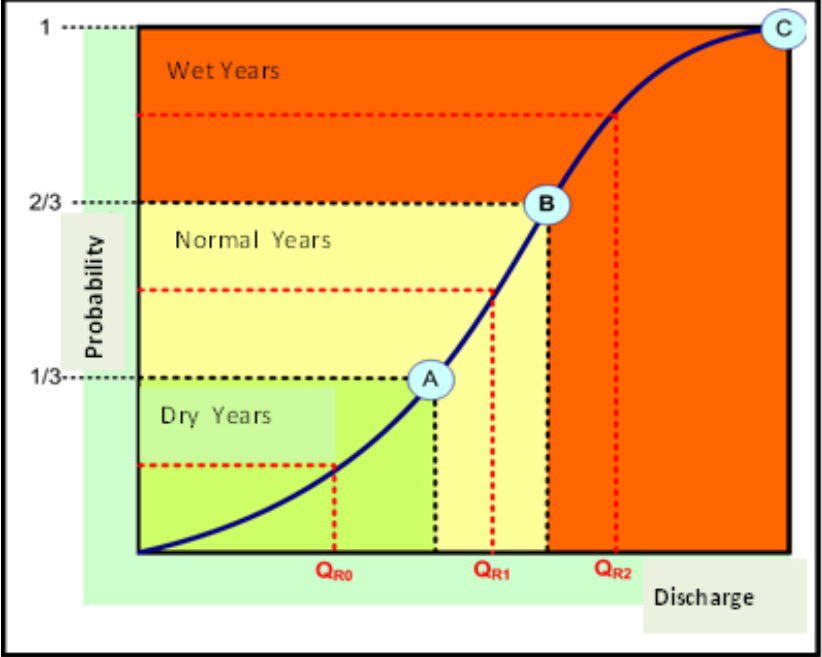

Fig. 1. Class division based on probability in Markov model

\subsection{Monitoring Quality Station in Saguling Reservoir}

Monitoring of water quality in Saguling was conducted regularly every three months within one year span, with each taken in March, June, September, and December respectively. There were 11 locations of Saguling quality monitoring stations: Nanjung Station (input), Batujajar, Cipatik Muara, Muara Ciminyak, Cimerang, Tjihaur, Muara Cijere, Cijambu Muara, Muara Tjihaur, Turbine Intake and Tailrace. The monitoring was conducted on forty-four (44) water quality parameters which consist of physical and chemical parameters. Main study location in this research was Nanjung Station, Muara Ciminyak Station, and Intake Turbine station as shown in Figure 2.

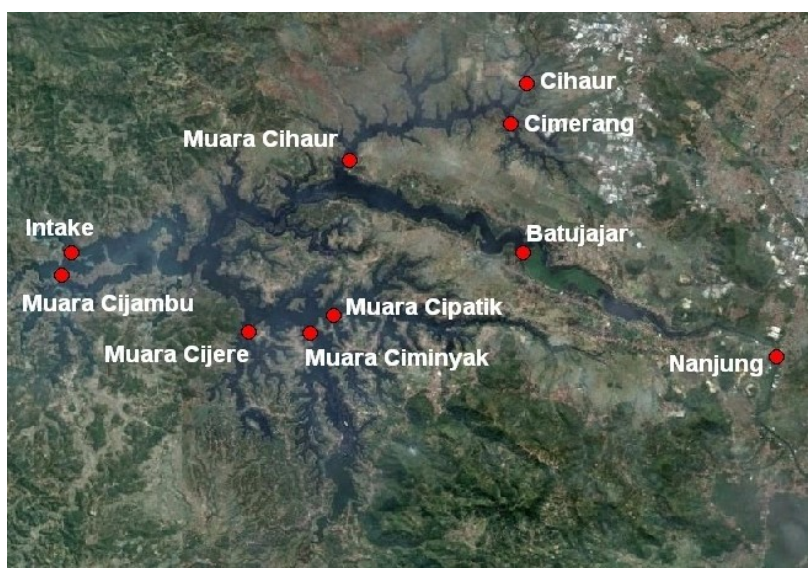

Fig. 2. Location of Monitoring Quality Station in Saguling Reservoir 


\subsection{The Measurement of Saguling Water Quality Index}

WQI method does not distinguish between physical, chemical, and biological contaminants. All types of contaminants are given equal value [18]. WQI method is quite easy and simple with the following equation:

$$
\mathrm{WQI}=\left(\sum[\mathrm{Ci} / \mathrm{Pi}]\right) / \mathrm{n}
$$

$$
\begin{aligned}
& \mathrm{WQI}=\text { quality index (water quality index) } \\
& \mathrm{Ci}=\text { concentration of the variable } \mathrm{i} \\
& \mathrm{Pi}=\text { quality standards for variable } \mathrm{i} \\
& \mathrm{n}=\text { number of variable }
\end{aligned}
$$

Source or basis for determining the water quality was based on WQI which was based on research by

\begin{tabular}{|c|c|c|c|c|}
\hline \multirow{2}{*}{ No } & \multirow{2}{*}{ WQI Value } & \multicolumn{2}{|c|}{ Water Quality } & \multirow{2}{*}{ Recommendation } \\
\hline & & Class & Status & \\
\hline 1 & $\mathrm{WQI} \leq 0.30$ & 1 & Very clean & $\begin{array}{l}\text { No treatment } \\
\text { necessary. } \\
\text { Suitable for all } \\
\text { kind of water } \\
\text { usage. }\end{array}$ \\
\hline 2 & $\begin{array}{l}0.31 \leq \mathrm{WQI} \leq \\
0.89\end{array}$ & 2 & Clean & $\begin{array}{l}\text { After treatment, it } \\
\text { can be used for } \\
\text { drinking and } \\
\text { agriculture. } \\
\text { Without treatment, } \\
\text { can be used for } \\
\text { fishery. }\end{array}$ \\
\hline 3 & $\begin{array}{l}0.90 \leq \mathrm{WQI} \leq \\
2.49\end{array}$ & 3 & $\begin{array}{l}\text { Slightly } \\
\text { polluted }\end{array}$ & $\begin{array}{l}\text { Unsuitable for } \\
\text { drinking and } \\
\text { agriculture. If } \\
\text { there's no choice, } \\
\text { use it after } \\
\text { treatment. Without } \\
\text { treatment, can be } \\
\text { used for livestock, } \\
\text { recreation, and } \\
\text { sports purposes. }\end{array}$ \\
\hline 4 & $\begin{array}{l}2.50 \leq \mathrm{WQI} \leq \\
3.99\end{array}$ & 4 & $\begin{array}{l}\text { Moderately } \\
\text { polluted }\end{array}$ & $\begin{array}{l}\text { Can be used for } \\
\text { irrigation and } \\
\text { industrial purposes } \\
\text { after a proper } \\
\text { treatment. }\end{array}$ \\
\hline 5 & $\begin{array}{l}4.00 \leq \mathrm{WQI} \leq \\
5.99\end{array}$ & 5 & $\begin{array}{l}\text { Heavily } \\
\text { polluted }\end{array}$ & $\begin{array}{l}\text { After an } \\
\text { appropriate } \\
\text { treatment can be } \\
\text { used for heavy } \\
\text { industrial activities } \\
\text { without human } \\
\text { body contact. }\end{array}$ \\
\hline 6 & $\mathrm{WQI} \geq 6.00$ & 6 & Dirty & $\begin{array}{l}\text { Unsuitable for any } \\
\text { purpose. Requires } \\
\text { an extensive } \\
\text { treatment. }\end{array}$ \\
\hline
\end{tabular}
Altansukh and Davaa that conducted in Tuul River, Mongolia. Determination of water quality based on WQI value can be seen in Table 2 .

Table 2. Determination of Water Quality Based on WQI Value

\section{Discussion}

\subsection{Raw Water Dicharge Allocation at Saguling Reservoir}

Discharge analysis in Citarum Cascade Reservoir started from the discharge observation data at Saguling Reservoir, namely Nanjung discharge station as primary station and Safuling discharge station as secondary station. Figure 3 shows that the average monthly discharge of Nanjung Station and Saguling Station have the same monthly pattern in both data series of 19201980 and 1986-2013.
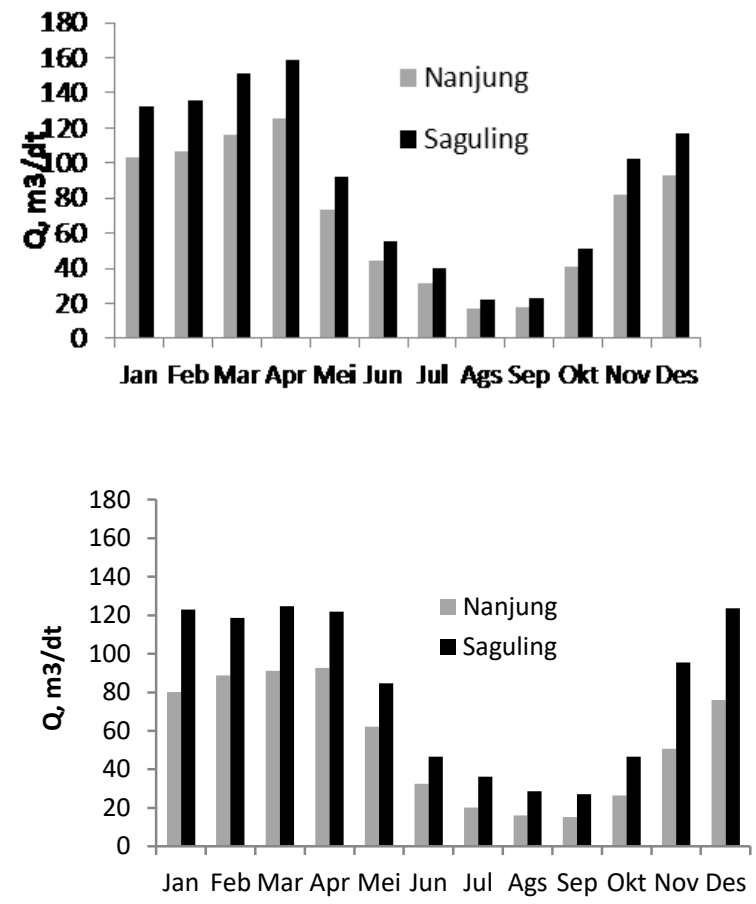

Fig.3. Monthly Average Discharge Fulucation in Nanjung Statin and Saguling Station Within Two Different Time Periods

Drinking water allocation that the Saguling Reservoir can provide is based on the discharge plan of dry R5 or dry R10 which can be seen in Table 3 .

\subsection{Division of Discharge Class of Saguling Water by Year}

Distribution of research observation year (1999-2013) was conducted by Markov Discreet Method. It was divided into dry, normal, and wet years. The class divisions were performed in Nanjung, Muara Ciminyak, and Turbine Intake Stations. The class divisions in dry, normal, and wet years in each station can be seen in Table 4. 
Table 4. Determination of Dry, Normal, Wet Years according to Markov Discreet Method based on Discharge Data of Saguling Reservoir

\begin{tabular}{lll}
\hline Dry Years (0) & Normal Years (1) & Wet Years (2) \\
\hline 2002 & 1999 & 2002 \\
2003 & 2000 & 2003 \\
2004 & 2008 & 2004 \\
2006 & 2009 & 2006 \\
2011 & 2012 & 2011 \\
\hline
\end{tabular}

\subsection{The Average Value of WQI of Overall Monitoring Post in Saguling Reservoir}

Based on Figure 4, it was found that based on the average value of WQI for each monitoring location station in Saguling Reservoir. Monitoring location that has the smallest WQI value was Muara Ciminyak Station with WQI value of 3,05. The monitoring location that has the highest WQI in this case showed the highest pollution level was Nanjung monitoring location.
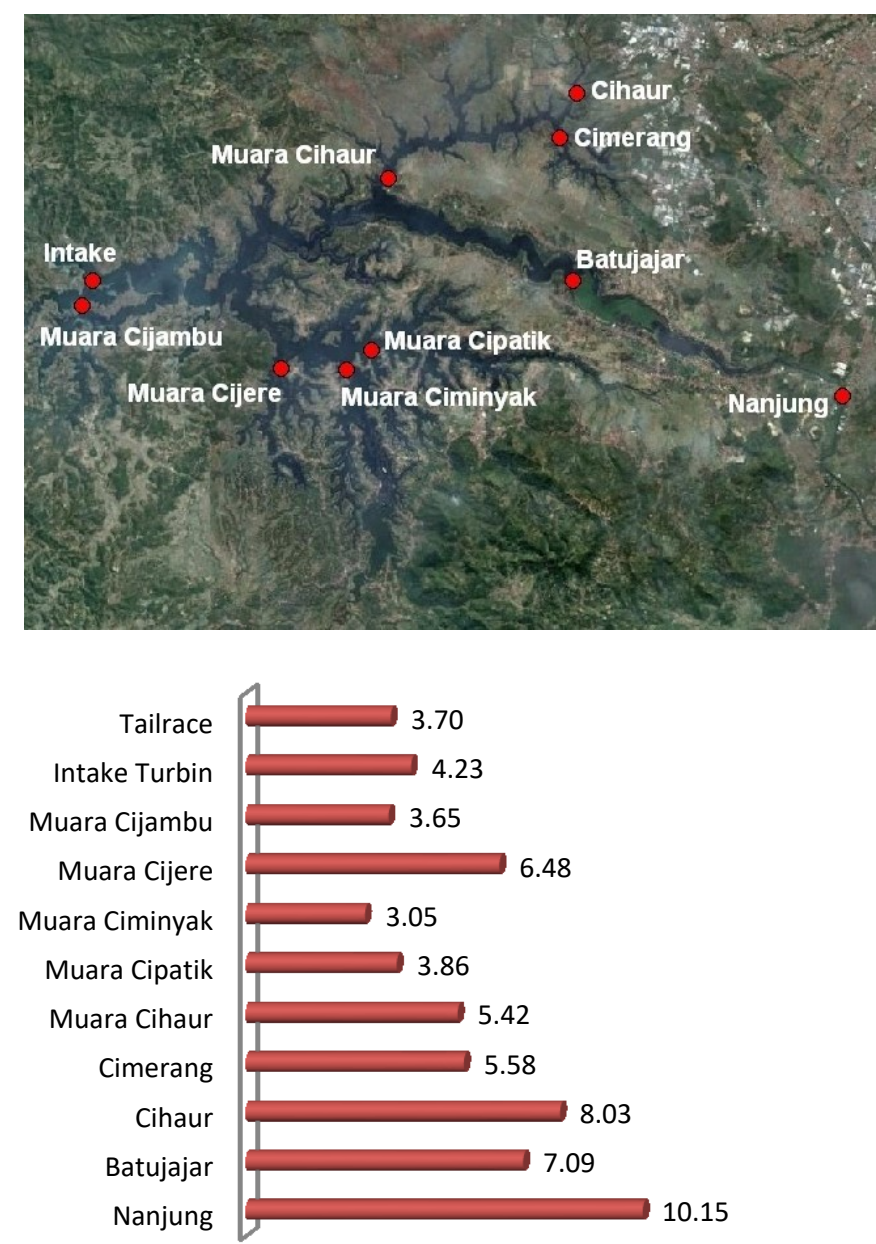

Fig.4. The average WQI value of each monitoring station in Saguling Reservoir
Determination of water quality based on WQI value (Altansukh \& Davaa) can be seen in Table 5.

Table 5 Water Quality Status of Each Monitoring Station in Saguling Reservoir

\begin{tabular}{|c|c|c|}
\hline $\begin{array}{c}\text { Monitoring } \\
\text { Location }\end{array}$ & $\begin{array}{c}\text { WQI Value } \\
\text { (Average) }\end{array}$ & Status \\
\hline Nanjung & 10,150 & Dirty \\
\hline Batujajar & 7,092 & Dirty \\
\hline Cihaur & 8,035 & Dirty \\
\hline Cimerang & 5,575 & Heavily polluted \\
\hline Muara Cihaur & 5,416 & Heavily polluted \\
\hline Muara Cipatik & 3,858 & $\begin{array}{c}\text { Moderately } \\
\text { polluted }\end{array}$ \\
\hline Muara Ciminyak & 3,046 & $\begin{array}{c}\text { Moderately } \\
\text { polluted }\end{array}$ \\
\hline Muara Cijere & 6,482 & Dirty \\
\hline Muara Cijambu & 3,650 & $\begin{array}{c}\text { Moderately } \\
\text { polluted }\end{array}$ \\
\hline Intake Turbin & 4,227 & Heavily polluted \\
\hline Tailrace & 3,704 & $\begin{array}{c}\text { Moderately } \\
\text { polluted }\end{array}$ \\
\hline
\end{tabular}

The high value of WQI or the high pollution in Nanjung Station is caused by the land-use in Nanjung watershed which is dominated by industry and household. The previous surveys informed that the main types of industry in Citarum watershed are textile industry, leather tanning industry, food industry, and electroplating industry. Based on a study conducted by Environmental Agency of West Java Province in 2007, there were 359 companies that are divided into 11 different industry sectors, located in four administrative areas along the upstream of Citarum River. Among those industrial sectors, textile industry is one of the sectors that need to be considered because of its most dominant number. Other industrial sector such as electroplating, pharmaceuticals, metals, food/beverages also need attention. Detailed data on the number of industry of inventory result of Environmental Agency of West Java Province (2007) can be seen in Table 6.

Table 6 Data of the Number of Industry

\begin{tabular}{|c|c|c|c|c|c|c|}
\hline No & $\begin{array}{c}\text { Industry } \\
\text { Sector }\end{array}$ & \multicolumn{5}{|c|}{ Municipality/City } \\
\hline & & $\begin{array}{c}\text { Sumedang } \\
\text { Regency }\end{array}$ & $\begin{array}{c}\text { Bandung } \\
\text { Regency }\end{array}$ & $\begin{array}{c}\text { Bandung } \\
\text { City }\end{array}$ & $\begin{array}{c}\text { Cimahi } \\
\text { City }\end{array}$ & Total \\
\hline 1 & Textile & 10 & 152 & 54 & 46 & 262 \\
\hline 2 & $\begin{array}{c}\text { Electrop } \\
\text { lating }\end{array}$ & 0 & 5 & 9 & 5 & 19 \\
\hline 3 & Leather & 1 & 0 & 1 & 0 & 2 \\
\hline 4 & $\begin{array}{c}\text { Chemic } \\
\text { al }\end{array}$ & 0 & 4 & 0 & 0 & 4 \\
\hline 5 & $\begin{array}{c}\text { Pharmac } \\
\text { eutical }\end{array}$ & 0 & 3 & 3 & 3 & 9 \\
\hline 6 & Paper & 0 & 2 & 1 & 0 & 3 \\
\hline 7 & Paint & 0 & 1 & 0 & 2 & 3 \\
\hline 8 & $\begin{array}{c}\text { Integrat } \\
\text { ed IPAL }\end{array}$ & 0 & 2 & 0 & 0 & 2 \\
\hline 9 & $\begin{array}{c}\text { Food/Be } \\
\text { verage }\end{array}$ & 1 & 3 & 10 & 10 & 24 \\
\hline
\end{tabular}




\begin{tabular}{|c|c|c|c|c|c|c|}
\hline No & $\begin{array}{c}\text { Industry } \\
\text { Sector }\end{array}$ & \multicolumn{5}{|c|}{ Municipality/City } \\
\hline & & $\begin{array}{c}\text { Sumedang } \\
\text { Regency }\end{array}$ & $\begin{array}{c}\text { Bandung } \\
\text { Regency }\end{array}$ & $\begin{array}{c}\text { Bandung } \\
\text { City }\end{array}$ & $\begin{array}{c}\text { Cimahi } \\
\text { City }\end{array}$ & Total \\
\hline 10 & Garment & 0 & 0 & 2 & 0 & 2 \\
\hline 11 & Metal & 0 & 0 & 1 & 6 & 7 \\
\hline & Total & 15 & 176 & 93 & 75 & 359 \\
\hline
\end{tabular}

\subsection{The Average WQI Value Based on Grouping of Monitoring Station Location}

\begin{tabular}{|l|l|}
\hline \multicolumn{2}{|l|}{ Distribution of Monitoring Station based on Location of } \\
Saguling Reservoir & Nanjung \\
\hline \multirow{4}{*}{ Inlet } & Batujajar \\
\hline \multirow{5}{*}{ North of Reservoir (Middle) } & Cihaur \\
\cline { 2 - 2 } & Cimerang \\
\cline { 2 - 2 } & Muara Cihaur \\
\cline { 2 - 2 } & Muara Cipatik \\
\cline { 2 - 2 } & Muara Ciminyak \\
\cline { 2 - 2 } & Muara Cijere \\
\cline { 2 - 2 } & Muara Cijambu \\
\hline \multirow{4}{*}{ Outlet } & Intake Turbin \\
\cline { 2 - 2 } & Tailrace \\
\hline
\end{tabular}

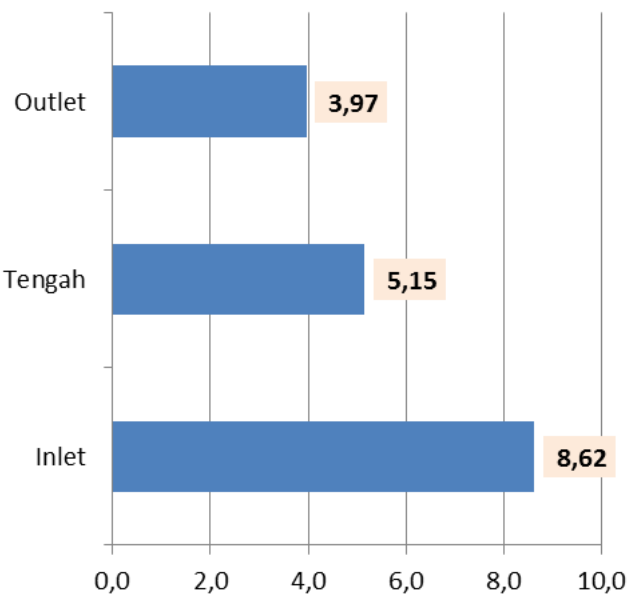

Fig.5. The average value of EQU based in the Location Grouping of Monitoring Station

Grouping of the entire monitoring station into three main location of Reservoir (inlet, middle, and outlet) and WQI value based on the location division can be seen in Figure 5. Based on Figure 5, it can be seen that the highest pollution is in the inlet area of Saguling Reservoir discharge, in this case from the upstream Citarum watershed and the lowest pollution is in outlet location. This is in accordance with the dilution phenomenon occurs along the reservoir or water body which is the increasingly away from the inlet location with high pollution, the pollution can decrease.

\subsection{WQI value based on the Discharge Class Division (Dry, Normal, and Wet)}

Water quality of each monitoring location cannot be separated from the volume condition occurred in Saguling Reservoir. In obtaining the actual status of reservoir, it is necessary to determine the quality of reservoir with the scenario of year condition or the volume occurred, in this case the dry, normal, and wet year. The WQI value of each monitoring location the condition series of dry, normal, and wet year can be seen in Table 7. The specific WQI value in the year condition of wet, normal, and dry for all monitoring station of Saguling Reservoir can be sen in Figure 6, Figure 7, and Figure 8.

Table 7. WQI Value of Each Monitoring Station in the Discharge Class Division of Wet, Normal, and Dry Year

\begin{tabular}{|l|l|l|l|l|l|}
\hline $\begin{array}{l}\text { Year } \\
\text { Division } \\
\text { Based on } \\
\text { Discharge } \\
\text { Class }\end{array}$ & Nanjung & Batujajar & Cihaur & Cimerang & $\begin{array}{l}\text { Muara } \\
\text { Cihaur }\end{array}$ \\
\hline Drw & 14,277 & 10,893 & 11,681 & 6,494 & 9,041 \\
\hline Normal & 8,383 & 5,689 & 7,781 & 5,206 & 4,053 \\
\hline Wet & 7,792 & 4,693 & 4,642 & 5,025 & 3,154 \\
\hline
\end{tabular}

Table 7. WQI Value of Each Monitoring Station in the Discharge Class Division of Wet, Normal, and Dry Year (Cont.)

\begin{tabular}{|c|c|c|c|c|c|c|}
\hline $\begin{array}{c}\text { Year } \\
\text { Division } \\
\text { Based on } \\
\text { Discharge } \\
\text { Class }\end{array}$ & $\begin{array}{c}\text { Muara } \\
\text { Cipatik }\end{array}$ & $\begin{array}{c}\text { Muara } \\
\text { Ciminyak }\end{array}$ & $\begin{array}{c}\text { Muara } \\
\text { Cijere }\end{array}$ & $\begin{array}{c}\text { Muara } \\
\text { Cijambu }\end{array}$ & $\begin{array}{c}\text { Intake } \\
\text { Turbin }\end{array}$ & Tailrace \\
\hline Dry & 5,818 & 4,051 & 7,244 & 5,397 & 6,270 & 4,074 \\
\hline Normal & 3,058 & 2,734 & 6,675 & 2,785 & 3,587 & 3,811 \\
\hline Wet & 2,697 & 2,353 & 5,526 & 2,768 & 2,823 & 3,227 \\
\hline
\end{tabular}

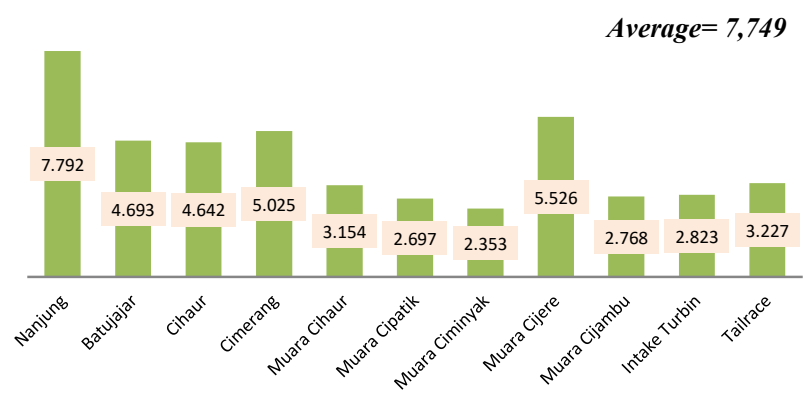

Fig. 6. WQI Value of Each Monitoring Station in the Discharge Class Division of Wet Year

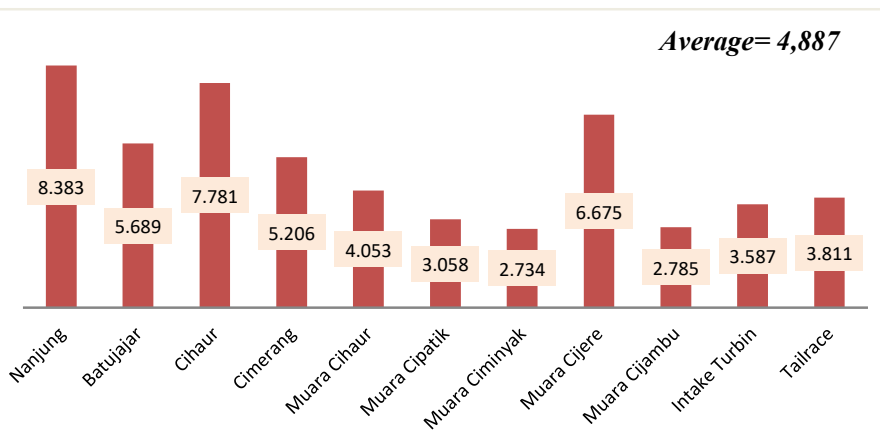

Fig.7. WQI Value of Each Monitoring Station in the Discharge Class Division of Normal Year 
Average $=4,064$

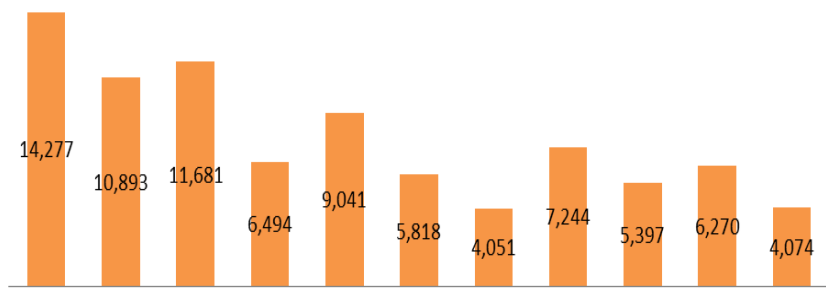

Nanjung Batujajar Cihaur Cimerang Muara Muara Muara Muara Muara Intake Tailrace Cihaur Cipatik Ciminyak Cijere Cijambu Turbin

Fig.8. WQI Value of Each Monitoring Station in the Discharge Class Division of Dry Year

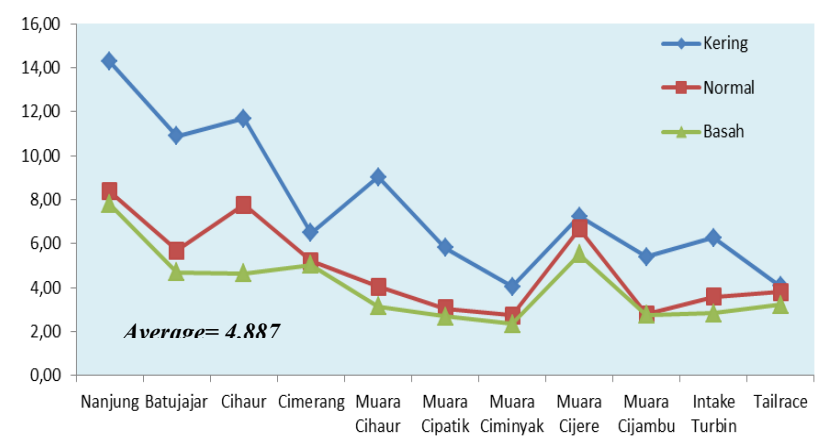

Fig.9. WQI Value Graph in Each Monitoring Station in Dry, Normal, and Wet Condition

Based on Figure 9, the highest WQI value is gained from the dry year, followed by the normal year, then, the wet years. It happened in each monitoring station in Saguling Reservoir. This was in accordance with the consistency of flow rate and concentration where it tend to be low in the dry season and the pollution concentration will increase. On the contrary, the reservoir flow rate increased in the rainy season, therefore the pollution concentration will decrease due to the dilution in the reservoir.

Based on Figure 9, the highest WQI value is gained from the dry year, followed by the normal year, then, the wet years. It happened in each monitoring station in Saguling Reservoir. This was in accordance with the consistency of flow rate and concentration where it tend to be low in the dry season and the pollution concentration will increase. On the contrary, the reservoir flow rate increased in the rainy season, therefore the pollution concentration will decrease due to the dilution in the reservoir.

\section{Conclusion}

The calculation allocation of raw water discharge for Saguling Reservoir in order to fulfill the needs of raw water in Bandung Metropolitan Area is 46,92 m3/second (R5 dry for irrigation raw water supply) and 29,53 92 $\mathrm{m} 3 /$ second (R10 dry for drinking raw water). The pollution load in Saguling Reservoir is a function of pollutant concentration and quantity or discharge occurred in the reservoir. This is demonstrated by the research of water pollution in Saguling Reservoir with Markov discrete approach and the determination of Water Quality Index (WQI) in the condition of dry, normal, and wet year. Based on the water quality analysis by Water Quality Index (WQI) method, it was found that the WQI Value in Muara Ciminyak Station is 4,051 in the dry year condition; 2,374 in normal year condition; and 2,353 in wet year condition. The monitoring location of this Muara Ciminyak Station is the most qualified as an option in the intake location of raw water supply from Saguling Reservoir. Utilization of Saguling Reservoir as an alternative potency of raw water supply requires careful target and preparation. Indepth calculation of Saguling Reservoir capability in terms of quantity and quality as an alternative of raw water needs to be done.

\section{References}

1. Kazi et al : Assessment of Water Quality of Polluted Lake using Multivariate Statistical Technique : A case Study. Ecotoxicol Environ Saf, 72, 301-309, (2009)

2. Singh, K.P., Malik, A., Mohan, D., Sinha, : Multivariate Statistical Techniques for The Evaluation of Spatial and Temporal Variations in Water quality of Gomti River (India): A Case Study. Water Research, 38, 3980-3992, (2004)

3. Aubert, A.H., Gascuel-Odoux, C., Merot, P : Annual Hysteresis of Water Quality: A Method to Analyse The Effect of Intra and Inter-annual Climatic Condition. Journal of Hydrology, 478, 29-39, (2013)

4. Lai et al : Development of A Water Quality Modeling System for River Pollution Index and Suspended Solid Loading Evaluation. Journal of Hydrology, 478, 89-101, (2013)

5. Merten, G. H.; Minella, J. P : The Identification of Sediment Sources in a Small Urban Watershed in Southern Brazil: 30, No. 11, October 2009, 1145-1153, (2002)

6. Djuangsih, N : Eutrofikasi di Waduk Saguling. Laporan Penelitian Hibah Bersaing. PPSDAL Lembaga Penelitian Universitas Padjadjaran, (1996) 
7. Hart, et al : Nutrient Budget for Saguling Reservoir, West Java, Indonesia. Water Research, 36, 2152-2160, (2002)

8. Andrade, E. M; Palacio, H. A. Q; Souza, I. H; Leao, R. A.O; Guerreiro, M. J. Land use effects in groundwater composition of an alluvial aquifer (Trussu River, Brazil) by multivariate techniques. Environmental Research, 106, pp. 170-178, (2008)

9. Guedes, H. A. S., Silva, D. D., Elesbon, A. A. A., Ribeiro, B. M., Matos, A. T., Soares, J. H. P : Application of Statistics Multivariate Analysis in Dove River. Jurnal Pertanian dan Teknik Lingkungan, 16, 558-563, (2002)

10. Laureano and Navar: An Assessment of Stream Water Quality of the Rio San Juan, Nuevo Leon, Mexico, 1995-1996. Journal of Environmental Quality, 31, 1256-1265, (2002)

11. Peterson et al: Process Identification by Principal Component Analysis of River WaterQuality Data. Ecological Modelling, 138, 193213, (2001)

12. Selle et al : Understanding Processes Governing Water Quality in Catchments Using Principal Component Scores. Journal of Hydrology, 486, 31-38, (2013)

13. Vialle, C., Sablayrolles, C., Lovera, M., Jacob, S., Huau, M. C., and Montrejaud-Vignoles, M: Monitoring of Water Quality from Roof Runoff : Interpretation Using Multivariate Analysis. Water Research, 45, 3765-3775, (2011)

14. Vonberg, D., Vanderborght, J., Cremer, N., Pütz, T., Herbst, M., and Vereecken, H : 20 Years of Long-Term Atrazine Monitoring in A shallow Aquifer in Western Germany. Water Research, 50, 294-306, (2014)

15. Fan, et al : Water Quality Management Based on Division of Dry and Wet Seasons in Pearl River Delta, China. Clean - Soil, Air, Water, 40, 381-393, (2012)

16. Sebastia, et al : Analysis of The Effects of Wet and Dry Seasons on A Mediterranean River Basin: Consequences for Coastal Waters and Its Quality Management. Ocean \& Coastal Management, 78, 45-55, (2013)

17. Altansukh and Davaa : Application of Index Analysis to Evaluate the Water Quality of The Tuul River in Mongolia. Journal of Water Resource and Protection, 3, 398-414, (2011)

18. Rosemond, Simone de, Duro, Dennis C. Dan Dubé, Monique : Comparative Analysis of Regional Water Quality in Canada using The
Water Quality Index. Environmental Monitoring Assessment, 156, 223-240, (2009)

19. Mahmood Q, Baig SA, Nawab B, Shafqat MN, Pervez A : Development of Low-Cost Household Drinking Water Treatment System of The Earthquake Affected Communities in Northern Pakistan. Desalination, 273, 316-320, (2011)

20. Mustapha, A., and Aris, A.Z : Spatial Aspect of Surface Water Quality Using Chemometric Analysis. Journal of Applied Sciences in Environmental Sanitation, 6, 411- 426, (2011) 